\title{
Hubungan Faktor-Faktor yang Mempengaruhi Konsumsi Asam Folat pada Ibu Hamil Trimester Pertama di Wilayah Kerja Puskesmas Kecamatan Barumun Kabupaten Padang Lawas Tahun 2017
}

\author{
Relation of Factors Affecting Consumption of Folic Acid in First Trimester Pregnant \\ Women On Work Area of Barumun District Health Center \\ Padang Lawas Regency in 2017
}

\author{
Netti Etalia br Brahmana*1, Mido EsterSitorus ${ }^{2}$ \\ ${ }^{1,2}$ Program Studi Kesehatan Masyarakat, Universitas Sari Mutiara Indonesia, Jln Kapten Muslim No. 77 Medan, \\ 20123, Indonesia \\ *Korespondensi Penulis: birink_netti@yahoo.com
}

\begin{abstract}
Abstrak
Asam folat berperan penting dalam pembentukan satu pertiga sel darah merah pada ibu hamil.Kekurangan Asam Folat bisa bikin anemia, setiap ibu hamil pasti akan diresepken tablet folic acid alias asam folat tadinya Cuma $50 \mathrm{mg}$, selama kehamilan meningkat jadi $800 \mathrm{mg}$ hingga 1 miligram perharinya. Penelitian ini bersifat analitik dengan menggunakan data primer yang diperoleh melalui wawancara responden dengan menggunakan kuesioner, dimana penelitian ini dilakukan di Wilayah Kerja Puskesmas Kec. Barumun Kab. Padang Lawas, yang menjadi populasi disini adalah seluruh ibu hamil yang mengkonsumsi asam folat dengan jumlah 83 responden. Berdasarkan hasil penelitian yang di peroleh dari 83 responden mayoritas berumur > 20 tahun sebanyak 72 orang (86,7\%), mayoritas responden Rutin sebanyak 56 orang $(67,5 \%)$, responden tidak Rutin sebanyak 27 orang $(32,5 \%)$, dan mayoritas responden Teratur sebanyak 58 orang $(69,9 \%)$. Berdasarkan hasil chi square diperoleh probabilitas value $(\mathrm{pV})=0,000$ dari tarif signifikan apabila $\mathrm{P}=0,000<0,05$ maka Ho diterima dimana lebih kecil $\mathrm{P}(0,000<0,05)$ maka dapat dinyatakan bahwa terdapat hubungan yang signifikan. Diharapkan kepada tenaga kesehatan untuk memberikan penyuluhan mengenai konsumsi asam folat pada trimester pertama. Supaya ibu hamil lebih mengerti tentang gizi ibu hamil.
\end{abstract}

Kata Kunci : asam folat, ibu hamil, trimester pertama

\begin{abstract}
Folic acid plays an important role in the formation of one third of red blood cells in pregnant women. Folic Acid deficiency can make anemia, every pregnant woman will definitely be prescribed folic acid tablets aka folic acid, only $50 \mathrm{mg}$, during pregnancy it increases to $800 \mathrm{mg}$ to 1 milligram per day. This research is analytical by using primary data obtained through interviewing respondents using a questionnaire, where this research was conducted in the District Health Center Work Area. Barumun Kab. Padang Lawas, which is the population here
\end{abstract}


are all pregnant women who consume folic acid with 83 respondents. Based on the research results obtained from 83 respondents the majority were $>20$ years old as many as 72 people (86.7\%), the majority of respondents were as many as 56 people (67.5\%), non-routine respondents as many as 27 people (32.5\%), and the majority of regular respondents are 58 people (69.9\%). Based on the chi square results obtained the probability value $(p V)=0,000$ from the significant tariff if $P=0,000<0,05$, then Ho is accepted where it is smaller $P(0,000<0,05)$ then it can be stated that there is a significant relationship. It is expected that health workers will provide counseling regarding consumption of folic acid in the first trimester. So that pregnant women understand more about the nutrition of pregnant women.

Keywords: Folic Acid, Pregnant Women, First Trimester

\section{PENDAHULUAN}

Kehamilan merupakan suatu keadaan fisiologis yang diharapkann setiap pasangan suami istri. Setiap pasangan menginginkan kehamilan berlangsung dengan baik bayi tumbuh sehat sesuai yang diharapkan dan lahirnya bayi yang sehat dan sempurna secara jasmaniah dengan berat badan yang cukup. Masa kehamilan adalah suatu fase penting dalam pertumbuhan anak karena calon ibu dan bayi yang dikandungnya membutuhkan gizi yang banyak (Notoatmodjo, 2011)

Menurut WHO/ World Health Organizatation, asam folat dikategorikan kelas A, artinya aman dikonsumsi ibu hamil.Hasil laporan dari WHO, 2/3 kasus NTD bisa diselamatkan dengan mengkonsumsi asam 400-600 mcg asam folat. Sejak tahun 1995, Australia mengizinkan beredarnya makanan yang diperkaya dengan asam folat sebagai upaya untuk menurunkan angka kejadian NTD. kematian ibu di Negara berkembang berkaitan dengan anemia pada kehamilan dan kebanyakan disebabkan oleh defisiensi besi dan perdarahan akut, bahkan tidak jarang keduanya saling berinteraksi.

Dinas Kesehatan Sumatera Utara, melihat masih banyaknya ibu hamil yang mengalami anemia di karenakan kurangnya mengkonsumsi zat besi atau asam folat. Untuk mengatasi masalah tersebut pemerintah Depkes RI sejak tahun 1970 telah melaksanakan suatu program pemberian tablet zat besi pada ibu hamil. (Suharsimi, 2013). Program ini dilaksanakan di puskesmas dengan mendistribusikan tablet tambah darah, dimana 1 tablet berisi $200 \mathrm{mg}$ fero sulfat dan 0,25 $\mathrm{mg}$ asam folat (setara dengan $60 \mathrm{mg}$ besi dan $0,25 \mathrm{mg}$ asam folat) (Depkes RI, 2008). 
Kekurangan Asam Folat Bisa Bikin Anemia, Setiap ibu hamil pasti akan diresepkan tablet folic acid alias asam folat oleh dokter kandungannya sejak awal kehamilan. Pasalnya, kebutuhan asam folat tadinya cum 50 mikrogram, selama kehamilan meningkat jadi 800 mikrogram hingga 1 miligram perharinya. Kalau tidak ibu hamil akan mengalami anemia megaloblastik. Gejalanya tak beda dengan anemia pada umumnya, yaitu lesu, mudah lelah, kurang darah, mudah capek , napas pendek, peradangan pada lidah, mual, nafsu makan hilang, sakit kepala, pingsan, pucat, dan agak kekuningan (Atikah Proverawati, 2010).

Kebutuhan rata-rata untuk ibu hamil adalah 1 tablet yang mengandung 320 mg FeSO4 (setara dengan $60 \mathrm{mg}$ di minum secara teratur dan benar selama 30 hari, $60 \mathrm{mg}$ zat besi dapat meningkatkan kadar hemoglobin (Hb) sebesar $1 \mathrm{~g}$. Tanpa persediaan zat besi yang memadai, ibu dapat mengalami anemia. Ibu yang anemia cenderung mengalami kelahiran prematur, sakit karena daya tahan tubuh yang rendah, melahirkan bayi dengan berat badan yang rendah (BBLR), serta perdarahan saat melahirkan dan nifas. Penyebab lain terjadinya anemia adalah jarak melahirkan yang terlalu dekat, malaria terjangkit cacing tambang, dan infeksi yang kronis (Astuti, 2014).

Berdasarkan hasil survey pendahuluan di Wilayah Kerja Puskesmas Kec. Barumun Kab. Padang Lawas di ketahui yang mengkonsumsi asam folat adalah sebanyak 33 orang (47,4\%) dan yang tidak mengkonsumsi asam folat sebanyak 50 orang $(52,6) \%$. Oleh karena itu peneliti tertarik melakukan penelitian tentang hubungan faktor - faktor yang mempengaruhi konsumsi asam folat pada ibu hamail trimester pertama di Wilayah Kerja Puskesmas Kec. Barumun Kab. Padang Lawas Tahun 2016.

Tujuan penelitian dalam penelitian ini yaitu untuk mengetahui hubungan faktor-faktor yang mempengaruhi konsumsi asam folat pada ibu hamil trimester pertama DI Wilayah Kerja Puskesmas Kec. Barumun Kabupaten Padang Lawas Tahun 2016.

\section{METODE PENELITIAN}

Penelitian ini adalah penelitian analitik yaitu untuk mengetahui hubungan faktor - faktor yang mempengaruhi konsumsi asam folat pada ibu hamil trimester pertama di Wilayah Kerja Puskesmas Kec. Barumun Kab. Padang Lawas. Penelitian ini dilakukan di Wilayah Kerja 
Puskesmas Kec. Barumun Kab. Padang Lawas. Jumlah sampel sebanyak 83 orang. Metode pengumpulan data dengan cara wawancara dan kuesioner. Menganalisa data yang ada dalam komputer, analisis data dilakukan untuk menjawab tujuan penelitian yang dicapai, analisis data dilakukan meliputi analisis univariat dan bivariat.

\section{HASIL DAN PEMBAHASAN}

Berdasarkan hasil penelitian umur responden umur responden dapat dilihat pada tabel berikut :

Tabel 1. Distribusi Responden Berdasarkan

\begin{tabular}{lll}
\hline Responden & F & $(\boldsymbol{\%})$ \\
\hline Umur & & \\
$<20$ Tahun & 11 & 13.3 \\
$>20$ tahun & 72 & 86.7 \\
Penghasilan & & \\
tidak mendukung & 38 & 45.8 \\
$\quad$ mendukung & 45 & 54.2 \\
Kebiasaan Makan & & \\
$\quad$ tidak teratur & 25 & 30.1 \\
$\quad$ Pratur & 58 & 69.9 \\
$\quad \begin{array}{l}\text { Promosi Pelayanan Kesehatan } \\
\text { tidak teratur }\end{array}$ & 25 & 30.1 \\
$\quad$ Konsumsi Asam Folat & 58 & 69.9 \\
Tidak rutin & & \\
Rutin & 27 & 32.5 \\
\hline
\end{tabular}

Tabel diatas sebagian besar berumur $>20$ tahun sebanyak 72 orang $(86,7 \%)$, responden berpenghasilan mendukung sebanyak 45 orang $(54,2 \%)$, responden kebiasaan makan teratur sebanyak 58 orang $(69,9 \%)$, responden Promosi Pelayanan Kesehatan teratur sebanyak 58 orang $(69,9 \%)$, responden Mengkonsumsi Asam Folat secara rutin sebanyak 56 orang $(67,5 \%)$. 
Tabel 2. Tabel Silang Berdasarkan Umur di Wilayah Kerja Puskesmas Kec. Barumun Kab. Padang Lawas Tahun 2017

\begin{tabular}{|c|c|c|c|c|c|c|c|c|}
\hline \multirow{3}{*}{ No } & \multirow{3}{*}{ Umur } & \multicolumn{7}{|c|}{ Konsumsi Asam Folat } \\
\hline & & \multicolumn{2}{|c|}{ Rutin } & \multicolumn{2}{|c|}{ Tidak Rutin } & \multicolumn{2}{|c|}{ Jumlah } & $\begin{array}{c}P \\
\text { Value }\end{array}$ \\
\hline & & Jlh & $\%$ & Jlh & $\%$ & Jlh & $\%$ & \multirow{4}{*}{0,000} \\
\hline 1 & $<20$ tahun & 9 & 10,8 & 2 & 2,4 & 11 & 13,3 & \\
\hline 2 & $>20$ tahun & 47 & 56,6 & 25 & 30,1 & 72 & 86,7 & \\
\hline & Jumlah & 56 & 67,5 & 27 & 32,5 & 83 & 100,0 & \\
\hline
\end{tabular}

Hasil uji bivariat menggunakan Chi-square menunjukkan bahwa nilai P-value sebesar $0,000<0,05$ artinya terdapat hubungan yang signifikan antara faktor-faktor yang mempengaruhi konsumsi asam folat pada ibu hamil trimester pertama di Wilayah Kerja Puskesmas Kec. Barumun Kabupaten Padang Lawas Tahun 2017.

Tabel 3. Tabel Silang Berdasarkan Penghasilan di Wilayah Kerja Puskesmas Kec. Barumun Kab. Padang Lawas Tahun 2017

\begin{tabular}{|c|c|c|c|c|c|c|c|c|}
\hline \multirow{3}{*}{ No } & \multirow{3}{*}{ Penghasilan } & \multicolumn{7}{|c|}{ Konsumsi Asam Folat } \\
\hline & & \multicolumn{2}{|c|}{ Rutin } & \multicolumn{2}{|c|}{ Tidak Rutin } & \multicolumn{2}{|c|}{ Jumlah } & $\begin{array}{c}P \\
\text { Value }\end{array}$ \\
\hline & & Jlh & $\%$ & Jlh & $\%$ & Jlh & $\%$ & \\
\hline 1 & Tidak Mendukung & 23 & 27,7 & 15 & 18,1 & 38 & 45,8 & 0,000 \\
\hline \multirow[t]{2}{*}{2} & Mendukung & 33 & 39,8 & 12 & 14,5 & 45 & 54,2 & \\
\hline & Jumlah & 56 & 67,5 & 27 & 32,5 & 83 & 100,0 & \\
\hline
\end{tabular}

Hasil uji bivariat menggunakan Chi-square menunjukkan bahwa nilai $P$-value sebesar $0,000<0,05$ artinya terdapat hubungan yang signifikan antara faktor-faktor yang mempengaruhi konsumsi asam folat pada ibu hamil trimester pertama di Wilayah Kerja Puskesmas Kec. Barumun Kabupaten Padang Lawas Tahun 2017. 
Tabel 4. Tabel Silang Berdasarkan Kebiasaan Makan di Wilayah Kerja Puskesmas Kec. Barumun Kab. Padang Lawas Tahun 2017

\begin{tabular}{|c|c|c|c|c|c|c|c|c|}
\hline \multirow{3}{*}{ No } & \multirow{3}{*}{ Kebiasaan Makan } & \multicolumn{7}{|c|}{ Konsumsi Asam Folat } \\
\hline & & \multicolumn{2}{|c|}{ Rutin } & \multicolumn{2}{|c|}{ Tidak Rutin } & \multicolumn{2}{|c|}{ Jumlah } & \multirow{2}{*}{$\begin{array}{c}P \\
\text { Valu }\end{array}$} \\
\hline & & Jlh & $\%$ & Jlh & $\%$ & Jlh & $\%$ & \\
\hline 1 & Tidak teratur & 2 & 2,4 & 23 & 27,7 & 25 & 13,3 & 0,000 \\
\hline \multirow[t]{2}{*}{2} & Teratur & 54 & 65,1 & 4 & 4,8 & 58 & 86,7 & \\
\hline & Jumlah & 56 & 67,5 & 27 & 32,5 & 83 & 100,0 & \\
\hline
\end{tabular}

Hasil uji bivariat menggunakan chi-square menunjukkan bahwa nilai P-value sebesar $0,000<0,05$ artinya terdapat hubungan yang signifikan antara faktor-faktor yang mempengaruhi konsumsi asam folat pada ibu hamil trimester pertama di Wilayah Kerja Puskesmas Kec. Barumun Kabupaten Padang Lawas Tahun 2017.

Tabel 5. Tabel Silang Berdasarkan Promosi Pelayanan Kesehatan Makan di Wilayah Kerja Puskesmas Kec. Barumun Kab. Padang Lawas Tahun 2017

\begin{tabular}{ccccccccc}
\hline & & \multicolumn{6}{c}{ Konsumsi Asam Folat } \\
\cline { 3 - 8 } No & $\begin{array}{c}\text { Promosi Pelayanan } \\
\text { Kesehatan }\end{array}$ & Rutin & & Tidak Rutin & Jumlah & Palue \\
\cline { 3 - 8 } & & Jlh & \% & Jlh & \% & Jlh & \% & \multirow{2}{*}{0,000} \\
\hline 1 & Tidak teratur & 2 & 2,4 & 23 & 27,7 & 25 & 13,3 & \\
2 & Teratur & 54 & 65,1 & 4 & 4,8 & 58 & 86,7 & \\
\hline & Jumlah & 56 & 67,5 & 27 & 32,5 & 83 & 100,0 & \\
\hline
\end{tabular}

Hasil uji bivariat menggunakan chi-square menunjukkan bahwa nilai P-value sebesar $0,000<0,05$ artinya terdapat hubungan yang signifikan antara faktor-faktor yang mempengaruhi konsumsi asam folat pada ibu hamil trimester pertama di Wilayah Kerja Puskesmas Kec. Barumun Kabupaten Padang Lawas Tahun 2017.

\section{Konsumsi Asam Folat}


Berdasarkan hasil penilitian menunjukkan bahwa dari 83 responden yang di teliti sebagian besar mengkonsumsi asam folat secara rutin sebanyak 56 orang (67,5\%). Dan sebagian kecil mengkonsumsi asam folat secara tidak rutin sebanyak 27 orang $(32,5 \%)$.

Menurut peneliti, dari hasil penelitian ini terlihat bahwa lebih dari $60 \%$ responden Mengkonsumsi asam folat secara rutin. Tetapi lebih dari 30\% responden yang lain melakukan konsumsi asam folat secara tidak rutin. Padahal mereka telah diberikan penyuluhan oleh pihak puskesmas setiap kali ibu hamil kunjungan ke puskesmas dan telah menjelaskan tentang manfaat dan cara mengkonsumsinya tetapi sebagian responden tidak mengikuti anjuran yang telah disampaikan dengan alasan lupa, dianjurkan untuk mengkonsumsinya 1 tablet sehari.

Penelitian yang dilakukan oleh Kristiyanasari (2010), di Kecamatan Bontonompo mendapatkan hasil bahwa jumlah ibu hamil yang sering mengkonsumsi sumber makanan asam folat adalah 13 orang $(28.9 \%)$ dari total responden 45 orang ibu hamil. Peneliti menyatakan bahwa ibu hamil yang sering mengkonsumsi ibu hamil hanya 2 dari 5 ibu hamil yang diperiksa. Jarangnya mengkonsumsi asam folat menyebabkan asupan asam folat pada ibu hamil sangat kurang.

Dari hasil uji analisis univariat didapatkan bahwa ibu hamil yang tidak mengalami defisiensi asam folat yakni sebanyak 43 orang atau 95.6\%. Hasil penelitian ini tidak sejalan dengan penelitian yang dilakukan oleh (Atikah, 2010) menunjukkan bahwa7 dari 10 wanita hamil mengalami defisiensi asam folat dan rentan terhadap disfungsi endothelial, termasuk endovaskular plasenta. Wanita hamil yang memiliki kadar asam folat di bawah $7 \mathrm{~nm} / \mathrm{L}$ mengalami 10,4 kali lipat risiko preklampsia.

\section{Hubungan faktor-faktor yang Mempengaruhi Konsumsi Asam Folat pada Ibu Hamil Trimester Pertama}

Berdasarkan hasil penelitian menunjukkan bahwa terdapat hubungan yang signifikan antara konsumsi asam folat pada ibu hamil trimester pertama di Wilayah Kerja Puskesmas Kec. Barumun Kab. Padang Lawas Tahun $2017 P=0,000<0,05$. Dari 83 responden yang mengkonsumsi asam folat secara rutin dan teratur sebanyak 56 orang (67,5\%). Dari 27 
responden yang mengkonsumsi asam folat secara tidak rutin dan tidak teratur sebanyak 27 orang $(32,5 \%)$.

Menurut asumsi peneliti, dari hasil penelitian ini terlihat bahwa ibu hamil yang mengkonsumsi asam folat secara rutin 1 tablet sehari sesuai anjuran tidak mengalami anemia megaloblastik. Sedangkan ibu hamil yang mengkonsumsi asam folat secara tidak rutin 1 tablet perharinya akan mengalami anemia megaloblastik.

Konsumsi asam folat merupakan satu-satunya vitamin yang kebutuhannya selama hamil berlipat dua. Sekitar 24-60\% wanita, baik di Negara sedang berkembang maupun yang telah maju, mengalami kekurangan asam folat karena kandungan asam folat di dalam makanan mereka sehari-hari tidak cukup untuk memenuhi kebutuhan ibu hamil. Kekurangan asam folat secara marjinal mengakibatkan peningkatan kepekaan, lelah berat, dan gangguan tidur.Dua kondisi pertama menyebabkan kaki kejang (Arisman, 2010).

\section{KESIMPULAN}

Berdasarkan hasil penelitian yang telah dilakukan dapat disimpulkan sebagai berikut :

1. Responden yang mengkonsumsi asam folat secara rutin sebanyak 56 orang (67,5\%). Selebihnya mengkonsumsi asam folat tidak rutin sebanyak 27 orang $(32,5 \%)$.

2. Responden sebagian besar ber umur $>20$ tahun sebanyak 72 orang $(86,7 \%)$. Sedangkan yang ber umur $<20$ tahun sebanyak 11 orang $(13,3 \%)$.

3. Responden sebagian besar yang berpenghasilan mendukung sebanyak 45 orang $(54,2 \%)$. Sedangkan yang berpenghasilan tidak mendukung sebanyak 38 orang (45,8\%).

4. Responden sebagian besar kebiasaan makan yang teratur sebanyak 58 orang (69,9\%). Sedangkan kebiasaan makan yang tidak teratur sebanyak 25 orang $(30,1 \%)$.

5. Responden sebagian besar promosi pelayanan kesehatan yang teratur sebanyak 58 orang $(69,9 \%)$. Sedangkan promosi pelayanan kesehatan yang tidak teratur sebanyak 25 orang $(30,1 \%)$.

6. Konsumsi asam folat berhubungan signifikan pada ibu hamil trimester pertama di Wilayah Kerja Puskesmas Kec. Barumun Kabupaten Padang Lawas Tahun 2017, nilai $P=0,000<$ 0,05 . 


\section{SARAN}

1. Bagi Puskesmas Kec. Barumun Kab. Padang Lawas

Disarankan kepada pihak puskesmas untuk secara rutin mengadakan penyuluhan kepada masyarakat khususnya ibu hamil yang berkunjung ke puskesmas tentang konsumsi asam folat pada ibu hamil trimester pertama sehingga ibu hamil lebih banyak paham tentang manfaat mengkonsumsi asam folat.

2. Bagi Ibu Hamil

Disarankan kepada ibu hamil untuk mengikuti anjuran tenaga kesehatan dalam mengkonsumsi asam folat sehingga dapat mencegah terjadinya anemia ibu hamil dan menghambat pertumbuhan bayi dalam kandungan.

\section{DAFTAR PUSTAKA}

Arikunto, Suharsimi. (2013). Prosedur Penelitian Suatu Pendekatan Praktik. Rineka Cipta. Jakarta.

Astuti, Maya. (2014). Buku Pintar Kehamilan. EGC. Jakarta.

Lailiyana. (2010). Gizi Kesehatan Reproduksi. EGC.Jakarta.

Mb, Arisman. (2010). Buku Ajar Ilmu Gizi, Gizi Dalam Daur Kehidupan. EGC. Jakarta.

Notoatmodjo, Soekidjo. (2011). Kesehatan Masyarakat Ilmu \& Seni. Rineka Cipta. Jakarta.

Proverawati, Atikah (2010). Nutrisi Janin \& Ibu Hamil, Cara Membuat Otak JaninCerdas. Nuha Medika. Yogyakarta.

Weni Kristiyanasari. (2010). Gizi Ibu Hamil. Nuha Medika.Yogyakarta. 